$15: 448$

ビデオ外科クリニック 虚 血 性 心 疾 患 (I)

\title{
V-48 内胸動脈使用冠動脈バイパス手術
}

\section{奈良県立医科大学 第 3 外科 \\ 北村 憼一郎河内寛治大山朝 賢高義 昭 森田隆一西井勤谷口繁樹}

過去 1 年 10 力月間に内胸動脈 (IUA) を左前下行枝あるいは対角枝へのバイパス材として 55 例に用いた. 右冠系, 回旋枝系にはSVGを用いた。術後検査を行った 34 例では IUA $100 \%$ 開存率を認めた。その手術手技は以下のと持 りである。

IUA の剥離：胸骨正中切開後, 開胸器で左儧胸壁を挙上するようにし電気メス (monopolar および bipolar), 止血 クリップを用いて剝離する，剣状突起付近から中枢に向かい鎖骨下近くまで剥離する。 IUA 中枢側の剝離は high frequency jet ventilation を用いると行いやすい. 1/2 希釈パパペリン液を噴霧してスパズムを予防する.SVGを大動 脈部分遮断下に大動脈と吻合した後 IUA 末梢 側を切断， $1.5 \sim 2.0 \mathrm{~mm}$ のプローブを深く通 し狭窄のないことを確認する。

IUA の吻合：体外循環, 心停止下に末ず回 旋枝系へのバイパス吻合を行う，IUA 吻合後 は心の反転が危険になるからである，IUA の 吻合は 8-0 プロリン系 2 本を用いた連続吻合で 行っている．8-0を用いれば連続吻合で十分で 開存性はきわめて良好である。停止中は一貫 して肺動脈ベントを用いている.

文 献 1) 北村惣一郎ほか: 循環科学 $5: 38$, 1985.

(A)

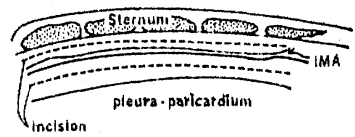

(B)

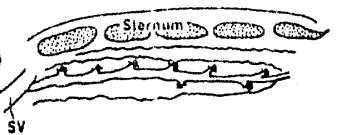

(c)

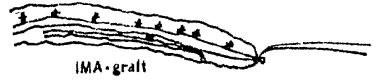

(D)

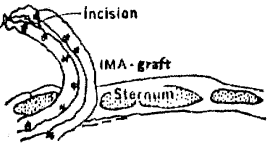

(E)

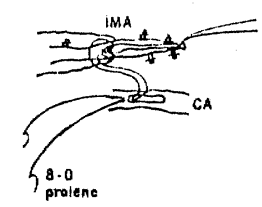

(F)

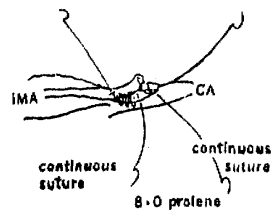

V-49 内胸動脈と静脈グラフトを使用した多枝 A-C バイパス手術

\author{
関西労災病院 心臓血管外科
}

清水幸宏

当院に和ける内胸動脈（IMA）と静脈グラフト（SVG）を併用した多枝 A-C バイパス手術例は 20 例である。男性 15 例，女性 5 例, 年㱓は $52 \sim 75$ 歳で LAD に 14 例, 対角枝に 6 例使用した。合併手術としては AVR+MVR（+ 3 枝バイパス）を 1 例に行った。平均バイパス数は 3.1 枝であり，手術死，病院死亡もなかった．呈示した症例は 52 歳 男性で，LAD，CX，RCA に狭窄を有する 3 枝病変例で LAD に IMA を使用した.

手術の要点 : 開胸器は通常の開心術と同じものを使用する. 左腹直筋の心膜, 腹膜との付着部を切離することによ 
り，左前胸壁を挙上し，手術台を左側へ回転させて IMA の観察を容易にしうる.

・IMA の豩離柱第 1 肋骨上縁まで行っている.

・大動脈部分遮断下に CX 領域への SVG を大動脈と吻合する.

- 送血管挿入後, IMA の未梢近くで切断し, free flow 測定後 toe から縦切開を加兄, その周团組織を覆布に固 定 後，パパベリンガーゼで被覆して後の LAD との吻合に備える.

-人工心肺開始, 心停止後 SVG と CX との末梢側吻合を最初に行い, 次いで IMA と LAD との吻合, 最後に SVG と RCA との吻合を行う.

・IMA の吻合は heel ヒ 7-0 プロリンの結節縫合を 3 本かけ結紮固定後, toe を回る連続縫合で行う.

- RCA と SVG との吻合開始時より徐々に復温を開始し，大動脈遮断解除後大動脈右側を部分遮断下に RCA への SVG と大動脈との吻合を行う．吻合終了後左房圧モニターチューブ挿入後人工心肺を終了する.

\section{V-51Ａ-C バイパスに和ける吻合法の工夫}

\section{大阪医科大学 胸部外科 \\ 武 内 敦 郎 須 磨 久 善}

われわれは，冠動脈枝と vein graft の吻合について従来連続縫合を敃こなってきたが，よりよき開存率を求めて， Cleveland Clinic の原法をもとに 7-0 絹糸による結節縫合法の利点について検討し，さらにその方法にわれわれの工 夫も加えたのでその要点を供覽した．結節縫合法は多数の両端針で graft と冠動脈枝のそれぞれの内膜面から針を刺入 することと，各糸の結紮操作を要する点が連続縫合法と異なる，その長所として，針の刺入が両血管とも，内膜側から 正確におこなわれ，吻合口のひずみのないような縫合が可能となり，吻合部狭窄の発生が防がれることとである，した がって冠動脈の内径が $1.5 \mathrm{~mm}$ 内外であったり, 壁が脆弱である場合や, ことに吻合口を直視し難い不利な視野の場合 では, 本法が有利となる.ただし Favaroloの原法では, いったん多数の系を放射状に冠動脈にかけた後, 改めて graft に糸をかけるために糸の整理に時間を要する，そこでわれわれは，冠動脈と graft に1本ずつ系をひきつづきかけなが ら整理する方法と，半周かけ終わればまずこれを結柇する方法を組み合わせて操作を簡便とした．

また両血管に糸を刺入する際に，すみやかによい刺入点を得ることが時間の節約と開存率の向上に重要であるので, graft の断端を立体的に展開し保持する holder を考案作成し, きわめて有用でめった.

これらの工夫の結果, 結節縫合法は通常の連続縫法に比べて所要時間もむしろ短縮できるので, 血管の性状や, 視野 の不利の場合にそな光て, 通常の連続縫合法と同様に習熟すべき技法と考兄る. 
ビデオ外科クリニック 虚 血 性 心 疾 患 (II)

\title{
V-52 79 歳の梗塞後 VSP (発症 99 時間) に対する緊急手術
}

\author{
- fibrin-glue-oxycellulose fixation の効用——
}

東京女子医科大学日本心臟血圧研究所 循環器外科

遠 藤 真 弘

79 歳男性, 急性心筋梗塞に陥り，CCU 飞昭和 59 年 12 月 8 日, 緊急入院した。心電図上， I, ${ }_{a} V_{L}, V_{2-6}$ で ST 上 昇を認めた. 血清酵素値は, 最大值で GOT 317, GPT 49, LDH 1434, CPK 2112, MB-CPK 123.5 単位と上昇した.

入院 9 時間後飞心雑音が聴取され，期外収縮が頻発し，血圧も収縮期圧 100 から $80 \mathrm{mmHg}$ へと低下した。 SwanGanz カテーテルで左 $\rightarrow$ 右短絡を証明し，梗塞後中隔穿孔と診断した.

血圧はさらにカテコラミン使用するも低下し，乏尿がつづき，BUN 69，Cr 2.9 と腎機能低下し，腹膜透析，IABP を使用するる，改善が認められない。

左 $\rightarrow$ 右短絡も $73 \%$ に徐从に增大し, 人工呼吸器管理を必要とした.

発症 108 時間, 中隔穿孔 90 時間目汇緊急手術を施行した.

手術を胸骨正中切開，cardioplegia に上る心停止下に行った。心尖部から前壁にかけて左室壁は瘤状になって妨り， これを $8 \times 6 \mathrm{~cm}$ 切除した.

心尖部よりの中隔に $2 \times 2 \mathrm{~cm}$ の中隔穿孔を認める. $2 \times 2 \mathrm{~cm}$ の欠損である.これを2-0 ゚ッチ付テフデック系で 右室から左室へと系を出し，全周 12 針U字にかける. $5 \times 5 \mathrm{~cm}$ のダクロンパッチを㐫て，中隔穿孔部を閉鎖した．

切除した部分はダクロンパッチを左室側，右室側にサンドイッチ状にあけ，0-2 針にてU字縫合，さらに連続縫合 した．壁はもろく，くずれそらであったが，注意深く系をかけた。

縫合部を固める目的で, 大動脈遮断解除前にフィブリノーゲン溶解液 $\mathrm{A}$ 液と, コンクライト $\mathrm{Ca}$, トロンビン, トラ ジロールから成るB液との混合によるフィブリン糊をオキシセル綿にしみこませ, フィルムに示すごとく, 縫合部を被 い,まったく出血を認めなかった，人工心肺から離脱も容易であった。

\section{V-53心筋梗塞後左心室瘤兼心室中隔穿孔の手術}

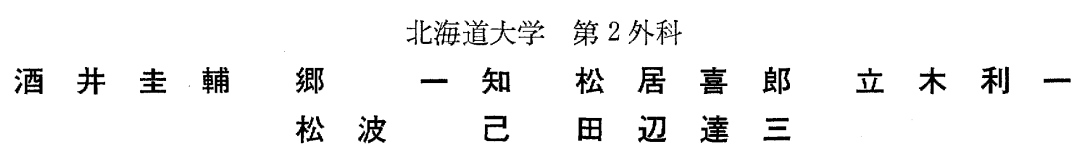

広沉な前壁梗塞後左心室瘤と心室中隔穿孔をきたした慢性期症例での standard aneurysmectomy と中隔穿孔部直接縫 合閉鎖の手術手技を供覧する。症例は 58 歳男性，手術適応は左心不全である.

手術は通常の中等度低体温併用体外循環, すなわち上行大動脈送血, 上下大静脈脱血, antegrade cardioplegia 法, ice slush 併用, 左心房ベント挿入下に手術を行う. 左心室瘤は LAD の左方で左室前面に位置している．この中央部 飞切開を加光, 左心室内腔の血栓の有無, 乳頭筋付着部を確認の上, 左心室疫痕部を幅約 $2.5 \mathrm{~cm}$, 長さ約 $5 \mathrm{~cm}$ にわた り切除する。室中隔穿孔は中隔の前方で，心尖部近くに位置し，その周囲は洀痕組織に团まれて和り，サイザーで測 った直径は $16 \mathrm{~mm}$ でめる. 中隔穿孔はそのサイズ, 位置, 周团組織の状況から直接縫合閉鎖が可能と判断され, 
pledget 付 2-0 タイクロン系を左心室側から穿孔中隔下縁に十分な bite をもってかケ，系の他端は右室前壁に出し， felt strip に通す．同様にすべての系をか沙終わってから結紮し，直接縫合閉 鎖する，心室瘤切除部む felt strip を buttress とし，その長軸方向全長に 2-0 タイクロン系の水平マットレス縫合をかけた後結禁する. この上にさらに $2-$ 0 タイクロン系による単純結節縫合をかけ，縫合部を補強し，手術を終了する。

\section{V-54心筋梗塞後左心室瘤に対する外科治療}

\section{永田昌久野垣英逸塩井健介土岡弘通}

心筋梗塞後の左心室瘤に対する瘤切除術は左心不全，血栓塞柽症，保存的治療で治療できない不整脈などの適応によ り行われ，血行動態の改善をみている．われわれの経験した左室瘤切除術の最近の 3 症例を合成，編集してビデオ供覧 した. 症例は 49〜60歳の男性で心筋梗塞の発症から 6 カ月〜 4 年を経過していた. 人工心肺体外循環の下で, 瘤はすべ て心膜との癒着強度であり，この制離は cardioplegia 注入後，心停止下のほらが容易であり，また血栓遊離の危険性も 少ないと思われた，瘤中央を十字切開し，血栓剥離，とくに新鮮血栓ではガーゼパッキングにより遊離血栓による塞栓 症防止をはかった．瘤中心部より放射状に切開し，内外側からの視診，触診により健常部との識別は容易であり，縫代 約 $1 \mathrm{~cm}$ を残して梗塞部切除，幅 $1 \mathrm{~cm}$ のテフロンフェルトのサンドイッチによりU字縫合括よび連続縫合で閉鎖し た. venting tube は肺動脈及び左室縫合部より挿入した，全例有意な冠動脈狭窄病変があり，A-C bypass 手術をあわせ 行った. 
ビデオ外科クリニック 虚 血 性 心 疾 患 $($ III $)$

\title{
V-55心筋梗塞による有茎性左心室内血栓の摘出術と $\mathrm{A}-\mathrm{C}$ バイパス術
}

\author{
福井循環器病院 外科 \\ 大中正光山下成哲田中孝
}

心筋梗塞後の左室内血栓は比較的よく見られる合併症であるが，可動性をるつ有茎性の血栓をみることはまれであ る.しかし，このよらな心腔内に浮遊せる有茎性の血栓は塞栓症の発生が危惧される。

症例は, 昭和 54 年に続き昭和 59 年 10 月に心筋梗塞を再発した 60 歳の男性で, 超音波心断層像や左室造影で心尖部 から中隔側飞可動性の心腔内に浮遊せる有茎性の欠損像を認めた。冠動脈所見では LAD 6 番々 CX 13 番に $90 \%$ の狭 窄を認めた. 手術は大動脈遮断後, cold blood cardioplegic solution を注入, その後左室の心尖部に約 $3 \mathrm{~cm}$ の縱切開を 加え, 約 $3 \times 2 \mathrm{~cm}$ の血栓をその茎部の心筋を含めて摘出した。そそのまま左室を開放したまま心臟を反転し， CX 13 番に SVG による distel anastomosis を施行. 完成後, 再び cold blood cardioplegic solution を graft と aortic root から注入．そして，厚手のテフロンフェルトを介して左室の心尖部の創部を縫合閉鎖，その際，左室内の空気抜きを十 分に施行. 大動脈遮断解除後しばらく graft から人工心肺からの加温送血を $50 \mathrm{ml} /$ 分くらいで注入し，準備がととのっ てから graft と aorta との anastomosis を施行した.

可動性の有茎性左室内血栓は塞栓症の発生原因となるので早急に手術が必要である.

\section{V-56＼cjkstart冠動脈病変を合併した弁膜症に対する弁置換， $\mathrm{A}-\mathrm{C}$ バイパス执よび OTCA の手術治験例}

\begin{tabular}{|c|c|c|c|c|c|c|c|c|c|c|c|c|}
\hline & & & & & 日本大学 & 第 2 & & & & & & \\
\hline 北 & 村 & 信 & $\equiv$ & 長谷川 & 隆 & 宮 & 本 & 晃 & 進 & 藤 & 正 & $=$ \\
\hline 陸 & 川 & 秀 & 智 & 塩 野 & 元 美 & 島 & 田 & 亮 & 新 & 野 & 成 & 隆 \\
\hline
\end{tabular}

症例は 60 歳の男性で，10 年前より大動脈弁閉鎖不全症と診断されていたが，自覚症状を欠くため放置していた。し かし約 3 年前より前胸部痛と失神発作が出現するようになり，精査目的で当科に入院した。 入院時の理学的検査では胸 骨左縁第 3 肋間に Levine $\mathbb{N}$ 度の収縮期・拡張期雑音が認められた。 心臟カテーテル検查では左室圧 $145 / 0 \mathrm{mmHg}$, 左 室拡張末期圧 $12 \mathrm{mmHg}$ ，大動脈圧 $120 / 50 \mathrm{mmHg}$, CI $3.6 \mathrm{l} / \mathrm{min} / \mathrm{m}^{2}, \mathbf{E F} 0.69$ で，さらに大動脈造影上，度の大動脈 弁逆流, 冠動脈造影上, 右冠動脈の Seg. 1, Seg. 2 飞 3 個所, 左冠動脈左前下行枝の Seg. $6,7,8$ に 3 個所の器質的狭 窄が認められた。左室造影ではSeg. 2 が hypokinetic であった。以上により多発性冠動脈狭窄病変を合併した大動脈弁 狭窄兼閉鎖不全症と診断され昭和 59 年 10 月 16 日に手術を施行した。 心筋保護は $28^{\circ} \mathrm{C}$ の低体温と心筀局所冷却さらに 選択的冠動脈注入法を併用した， $23 \mathrm{~mm}$ の SJM 弁で大動脈弁置換を行い，さらに，前下行枝 Seg. 8 に切開を加え Simpson-Robert Balloon を用いて Seg.7の狭窄を解除し対角枝と中隔枝の血行再建を行い，次いで切開部末梢側の狭 窄に対しても同様に OTCA を施行した. その後 Seg.3 と Seg. 8 にグラフトを吻合し手術を終了した。術後経過は良 好である。 


\section{V-57 小児多発性心室瘤の一手術治験}

\begin{tabular}{|c|c|c|c|c|c|c|c|c|c|c|c|c|}
\hline & & & & & 近畿大学 & 心臟多 & & & & & & \\
\hline 泉 & 弘 & 志 & 上 & 田 & 正 生 & 若 & 木 & 伸 & 夫 & 中 & 本 & 進 \\
\hline 佐 賀 & 俊 & 彦 & 西 & 岡 & 孝 & 奥 & & 秀 & 喬 & 城 & 谷 & 均 \\
\hline
\end{tabular}

小児期の心室瘤はきわめてまれであり，その原因はさまざまである，今回われわれは，正常冠動脈造影所見を呈し た，発生原因が異なると思われる多発性心室瘤例を経験したので，その手術を供覽し検討を加劣た。

症例は 14 歳男児, 自覚症状はまったくなく, 学校健診で胸部異常陰影を指摘された. 某院で縦隔腫瘍の 疑いで開胸

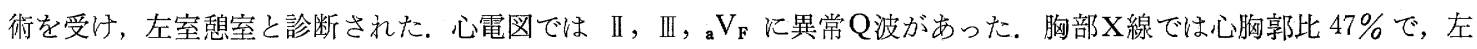
3 弓の部位に直径約 $3 \mathrm{~cm}$ の円形石灰化陰影を認めた。心 CT scan enhancement で, その異常陰影は左室と連続し, かつ石灰化された内部には血栓と造影剂が認められた，それとは別に，心血管造影で左室の心尖部和よび右室に心室瘤 を認めた，冠動脈造影では，走行異常和よび閉塞，狭窄等の所見は明らかでなかった。

手術は胸骨正中切開で行った. 冠動脈の走行異常は認められず, 石灰化した左室前側壁の心室瘤は $3 \times 3 \times 4 \mathrm{~cm} て ゙$, 表面は平滑は硬く，周囲は厚い㓔痕組織であった。瘤は切開せずに核出した。左室との交通孔は約 $6 \mathrm{~mm}$ 径で, 壁厚は 3〜 $5 \mathrm{~mm}$ ，内部は赤色血栓で㘯った。左室乳頭筋，僧帽弁に異常はなかった。心尖部に打ける左室瘤と右室瘤はとれぞ れ別個に瘤を切除しフコェルト付マットレス执よび連続縫合で閉鎖した，左室前側壁の心室瘤核出部の閉鎖は，通常の 全層縫合では LAD の血行障害をきたしたため，その縫合には特別な工夫を要した。 


\section{ビデオ外科クリニック 虚 血 性 心 疾 患 $(\mathbb{N})$}

\section{V-58小児高脂血症に合併した左冠動脈主幹部狭窄に対する 直視下バルンカテーテルによる拡大術}

楖原記念病院 外科

\section{菊 池利夫龍野勝彦高橋幸宏}

症例は 6 歳男児で生後 11 カ月時, 手背とアキレス腱の黄色腫に気づき某医大にて精查の結果, II a 型の高脂血症の 診断を受けた，家族には脂質代謝異常なく，家族性は否定された，食餌および薬物療法にて血中脂質正常化し，9カ月 後には黄色腫消失，以後専門医にて follow されていたが 6 歳時，路傍で倒れているのを発見され某病院入院. 冠動脈 造影にて左冠動脈起始部に $99 \%$ の狭窄を認め当院転院となった。

Treadmill 負荷開始 40 秒後 $\mathrm{I},{ }_{\mathrm{a}} \mathrm{V}_{\mathrm{L}}, \mathrm{V}_{2} \mathrm{~V}_{6}$ で $\mathrm{ST}$ 低下認め 2 分後前胸部痛出現で中止，薬物療法にても Treadmill 負荷 Stage II 20 秒にて胸痛出現するため外科治療となった：外科治療にあたっては，(1)大伏在静脈によるバイパス術 では遠隔の開存性に，(2)内胸動脈吻合では細すざるため開存性に，(3)鎖骨下動脈吻合は技術的に，(4)PTCA では技術 および適応上，それぞれ問題と考えられたため直視下バルンカテーテル拡大術の方針となった。

手術は胸骨正中切開，股動脈送血，右房脱血体外循環下，左房ベント，大動脈遮断，心管保護下に大動脈切開施行. 左冠動脈口には $1 \mathrm{~mm}$ 径の probe が入らず $0.45 \mathrm{~mm}$ 径の guide wire を介して $2 \mathrm{~mm}$ 径の Simpson バルンカテーテ ルを挿入， $90 \mathrm{psi}$ の圧で 2 回各 1 分間桩大した。これにより $2 \mathrm{~mm}$ 径の probe が挿入可能となり手術を終了した，術 後冠動脈造影にて左冠動脈起始部に $75 \%$ の残存狭窄を認めたが運動能は著しく改善した。

\section{V-59 CUSA による myocardial bridge の解除}

古 瀬 彰 進 藤 剛 毅 小 塚 裕 横 井 泰

左冠状動脈前下行枝が myocardial bridge 飞よって強く squeeze され，これによって心笳虚血が生じる症例に対して は supraarterial myotomy が施行されている。この手術には，心室穿孔，静脈損傷，動脈分枝損傷などの合併症が起こ りやすいことが知られている。このためわれわれは CUSA を使用して bridge の解除を行っているので，その実際につ いて供覽した。

手術は胸骨正中切開，部分体外循環下に行っている．前下行枝が存在すると推定される部位の心外膜をメスで切開し たのち，CUSA の出力を $50 \%$ として心外膜下脂肪組織を吸引除去していく．脂肺組織内の小静脈はこれとよって残る ので結森切離する，脂肪組織が除去されると， myocardial bridge 前後の冠状動脈が露出される．これによって bridge の全貌が判明するので，これを直接 CUSA によって吸引除去する.

この CUSA による bridge 解除手術は現在まで 2 症例に行った，症例 1 は 24 歳女，HCM を伴う例で，その手術の 実際を供覽した。症例 2 は 65 歳男, CAD を伴ら例で， 2 枝バイパスをあわせ行った。両例ともに合併症はなく，術後 冠状動脈撮影で，収縮期 squeezing が消失していることが確認されている.

CUSA を用いた myocardial bridge の解除手術は，安全かつ確実な手術であると考光ている。 


\title{
V-60 myocardial bridging に対する supraarterial myotomy に対する 1 治験例
}

\author{
大船共斎病院 胸部心臟血管外科 \\ 大平政人榊原直樹田中信行
}

myocardial bridging とは冠動脈の主要分枝が心筋内に埋没し，走行している状態をいう．本疾患が軽度の場合は問 題がないが，高度の場合は心筋虚血をもたらし，ときには心筋梗塞，突然死となるとの報告もある．

本疾患汶対する治療はむるん，内科的治療が第 1 選択となるが，これにても改善されない場合や，他覚的に心筋虚血 が明らか証明される場合は外科的適応となる。

今回，われわれは胸痛発作を主訴とした前下行枝領域の myocardial bridging (以下 MB) 飞対して supraarterial myotomy を施行し，著明な臨床症状执よび他覚的所見の改善を認めたので報告する.

症例 : 48 歳, 男性 会社員

主訴：前胸部胸痛発作

現病歴：昭和 59 年 3 月 30 日, 2 時間以上つづく前胸部痛めり, 某病院受診，4 月 18 日当科受診，以後薬物治療敊 こならも奏効せず 60 年 1 月 7 日手術のため入院となった。

術前心電図では triple master 拈よび isoproterenol で ST 低下, 胸痛の出現がみられた。 をた, CAG では NTG 投与に上る $90 \%$ 狭窄 (milking effect) がみられた，以上の所見より手術適応として1月17 日に手術を怙こなった。

MB は CAG 所見と一致した前下行枝領域にみられ, 長さ $35 \mathrm{~mm}$, 最も深い部位で $7 \mathrm{~mm}$ であり, distal 側よりょ ス㐨よびハサミを用いて切開した。

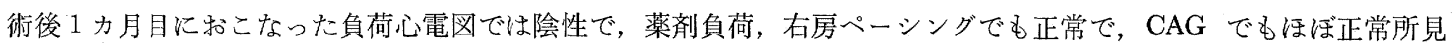
を示した。 